\title{
POTENSI BAHARI PULAU DERAWAN MENUJU \\ DESTINASI WISATA KOMPETITIF
}

\author{
Dadang Iham Kurniawan Mujiono
}

\begin{abstract}
As a nation Indonesia famous throughout the world as archipelago state, and those islands provide plenty of tourist destinations. Nowadays, the power of nations unlike in cold war era, where traditional security is measured as the main source of power, however in today's society non-traditional security become the main power, and one of them is tourism. As a country located in the coral triangle, Indonesia is surrounded by the shallow tropical marine ecosystem, where corals, fishes and other marine creatures are abundant. Indonesia in addition is the biggest contributor for the coral triangle area and Raja Ampat hosting the highest diversity of Marine world followed Derawan Island in East Kalimantan as the second place. This scientific paper will explain the potency of Derawan Island toward the competitive destination.

In order to analyse the topic, the concept of hospitality will implement and the type of data research is primary, since the author conducting field research in Derawan Island and visiting number of official government agencies which related with the topic of research. The type of the research is descriptive explanative where the author will describe the data and explain about the potency of Derawan Island.

The research shows that Derawan Island is located in the epicentre of marine biodiversity of the coral triangle. In addition Derawan Island also hosting two of six marine turtles in the world such as hawksbill and green turtle, in terms of dive spot, there are plenty of locations as the dive spot followed with extraordinary view and diversity of underwater world. Moreover related with accommodation, there are plenty of guesthouses, hotels and cottages and tourist can choose based on their budget.

Keywords: Derawan Island, Tourist, Hospitality.
\end{abstract}


Latar Belakang Masalah

Di tengah lesunya sektor energi minyak dan gas serta batubara di Indonesia, sektor pariwisata dapat menjadi pilihan alternatif dalam menunjang pertumbuhan perekonomian Indonesia. Sejak tahun 2013 sektor pariwisata masuk kedalam 4 sektor utama penunjang pendapatan devisa negara setelah minyak kelapa sawit, batubara, serta minyak dan gas bumi (Indonesia's Foreign. 2017). Hal tersebut diakibatkan karena kunjungan wisatawan mancanegara ke Indonesia tiap tahunnya selalu meningkat. Terbukti pada tahun 2010 total kunjungan wisatawan mancanegara mencapai 7.002 .944 dan meningkat menjadi 10.230.775 pada tahun 2015 (Foreign Tourist. 2017). Dengan meningkatnya jumlah kunjungan tersebut maka dapat merangsang terciptanya ekonomi kreatif masyarakat di sekitar daerah wisata serta meningkatkan partisipasi usaha lokal.

Menurut pasal 1 ayat 3 Undang-Undang Republik Indonesia nomor 10 Tahun 2009 tentang Kepariwisataan, pariwisata adalah berbagai macam kegiatan wisata dan didukung berbagai fasilitas serta layanan yang disediakan oleh masyarakat, pengusaha, Pemerintah, baik pusat atau daerah.

Ada berbagai macam jenis wisata yang dapat menjadi pilihan bagi para wisatawan untuk berlibur di Indonesia. Salah satunya yaitu wisata bahari yang menawarkan keindahan bawah laut Indonesia. Menurut Kamus Besar Bahasa Indonesia, wisata bahari adalah: pariwisata yang objeknya adalah laut isinya (berperahu, berselancar, menyelam, dan sebagainya). Adapun 
beberapa wisata bahari yang terkenal di Indonesia di antaranya Taman Nasional Bunaken di Sulawesi Utara, Kepulauan Raja Ampat di Papua, Taman Nasional Kepulauan Seribu di DKI Jakarta, serta Pulau Derawan yang terletak di Kabupaten Berau Kalimantan Timur. Lebih lanjut, sejak tertera di desain baru mata uang Indonesia Rp 20.000 Pulau Derawan menjadi salah satu icon baru wisata bahari di Indonesia.

\section{Gambar 1}

Desain Pulau Derawan Pada Mata Uang Rp 20.000 (Instrumen

\section{Pembayaran. 2017)}

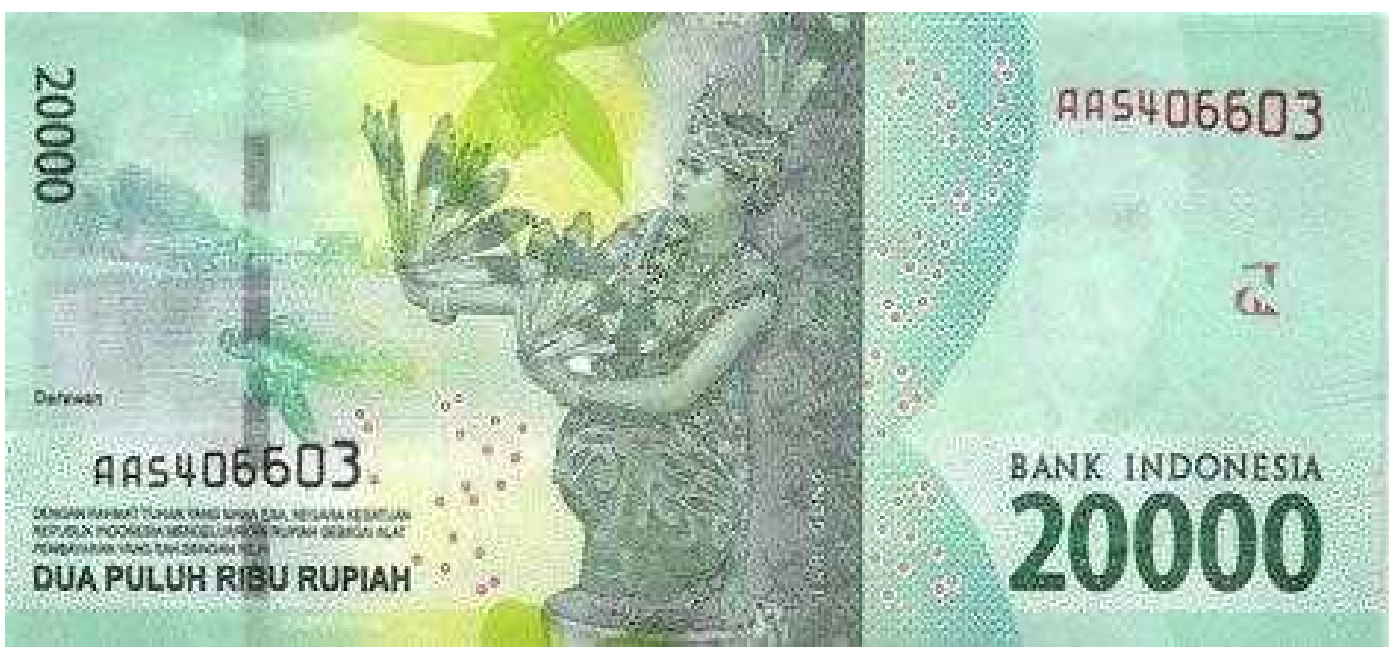

Pulau Derawan sendiri, secara administrasi berada di Kecamatan Pulau Derawan Kabupaten Berau, dan secara geografis terletak di sebelah timur Pulau Kalimantan dan bagian selatan selat Makassar yang terhubung dengan perairan Sulawesi dan Jawa (Derawan Island. 2017). Pulau ini sendiri memiliki luas 
wilayah 44,60 ha dengan jumlah penduduk mencapai 1.446 pada tahun 2016 (Jumlah Penduduk. 2017). Selain keberadaan Pulau Derawan, terdapat beberapa pulau di sekitar Pulau Derawan yang memiliki daya tarik obyek wisata bahari, di antaranya: Pulau Maratua, Sangalaki, dan Kakaban, dimana kesemua pulau tersebut masuk kedalam gugusan Kepulauan Derawan (Wiryawan Budi. 2005).

\section{Gambar 2}

Gugusan Pulau Derawan (3 Hari Menyingkap. 2017)

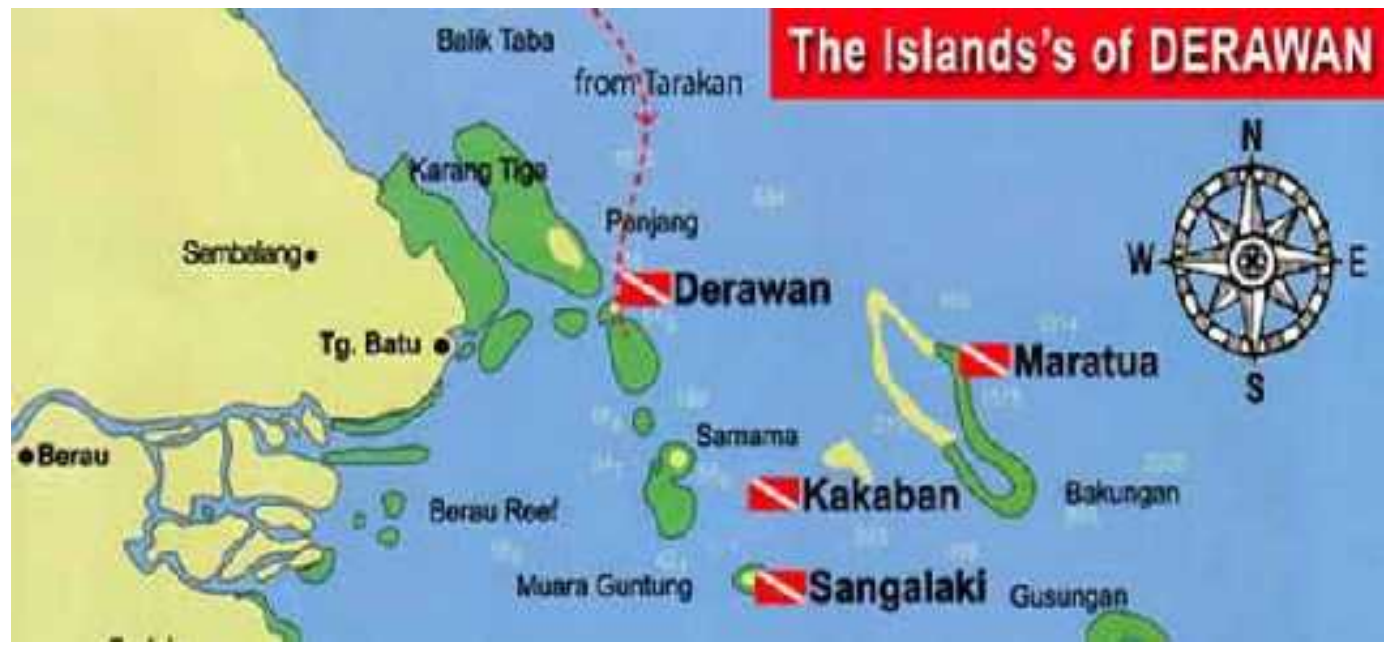

Pulau Derawan sendiri diberi nama sebagai obyek wisata bahari Kawasan Taman Laut karena merupakan bagian dari Ekoregion Laut Sulu-Sulawesi yang melintasi Indonesia, Malaysia dan Filipina. Ekoregion ini terletak di segitiga terumbu karang dunia atau Coral Triangle yang melintasi 6 negara di antaranya Indonesia, Malaysia, Filipina, Kepulauan Solomon, Timur Leste, dan Papua Nugini (Coral Treangle. 2017). Selain itu kawasan ini 
dikenal juga dengan nama Amazone of the Seas karena merupakan pusat kehidupan di laut dan keanekaragaman hayati yang paling kaya.

Melihat potensi bawah laut Pulau Derawan Tersebut, berdasarkan penelitian yang dikembangkan, kepulauan Derawan merupakan salah satu multi countries feeding ground terpenting di dunia. Secara umum terumbu karang yang ada di Kabupaten Berau merupakan keragaman terumbu karang tertinggi kedua setelah Raja Ampat (Wiryawan Budi. 2005)

Lebih lanjut, persebaran dan tutupan rata - rata terumbu karang di Pulau Derawan mempunyai tutupan keras rata - rata $17,41 \%$ dan tutupan persebaran kerang hidup sekitar 27,78\%. Lebih lanjut, sebagai wilayah yang kaya akan pasir putih, Pulau Derawan juga menjadi habitat asli bagi beberapa jenis penyu langka dan tergolong sebagai spesies yang terancam punah, seperti penyu hijau dan penyu sisik.

Kehadiran keanekaragaman hayati yang ada di Pulau Derawan menjadikan daya daya tarik bagi para wisatawan baik nasional dan mancanegara. Namun meskipun banyak potensi yang dimiliki, Pulau Derawan tetap memiliki beberapa permasalahan yang masih menjadi pekerjaan rumah bagi pemerintah daerah dalam menjadikan Pulau Derawan sebagai tempat pariwisata yang berkompetitif menuju wisata berkelas dunia. 
Metode Penelitian

Penelitian ini merupakan penelitian lapangan/field research (Loreen Wolfer, 2007: 334). Dengan observasi langsung di lokasi penelitian yakni di Pulau Derawan, Kabupaten Berau/Tanjung Redeb, secara khusus ekspektasi dari penelitian ini adalah untuk memperoleh pemahaman yang lebih detail dan mendalam mengenai implementasi program - program yang dimiliki oleh pemerintah Kabupaten Berau dalam mewujudkan wisata yang kompetitif dengan mengedepankan prinsip - prinsip yang sudah diatur dalam industri pariwisata. Selain itu juga akan membahas terkait dengan tantangan yang dihadapi industri pariwisata tersebut dan pemerintah Kabupaten Berau dalam mewujudkan tujuan yang telah disebutkan sebelumnya.

Kemudian, jika didasarkan pada tujuannya, maka penelitian ini termasuk dalam kategori penelitian eksplanatif, yakni berupaya untuk menjelaskan tentang upaya pemerintah Kabupaten Berau dalam mewujudkan Pulau Derawan sebagai destinasi wisata kompetitif. Merujuk pada data yang digunakan untuk menganalisis masalah, maka penelitian ini termasuk jenis peneltian kualitatif, dimana peneltian ini akan lebih menekankan pada pengungkapan makna dan proses dari berbagai faktor yang berhubungan dengan topik yang dibahas.

Lebih lanjut, secara kuantitas penelitian ini akan menggunakan banyak data kualitatif dan dilengkapi dengan beberapa data kuantitatif. Untuk menjaga validitas dan realibilitas data maka data diakses dari sumber-sumber terpercaya dan dapat dipertanggung jawabkan. Berdasarkan sumbernya yaitu 
data primer adalah dokumen terkait dan hasil wawancara dan lembar kuisioner serta data-data yang diperoleh secara langsung dari instansi terkait. Sedangkan data sekunder ditelusuri melalui jurnal online, jurnal cetak, artikel, buku, koran, majalah yang terkait dengan tema sentral dalam penelitian ini.

\section{Konsep Hospitality}

Menurut kamus Bahasa Inggris Oxford (2002), dikatakan bahwa hospitality adalah situasi penerimaan yang sangat ramah kepada tamu atau orang asing. Sedangkan menurut Kamus Bahasa Inggris Chambers (2001), dikatakan Hospitality merupakan sebuah kegiatan dengan memberikan hiburan kepada tamu atau orang asing dengan ramah tanpa mengharapkan imbalan, menunjukkan sikap baik, dan murah hati. Lebih lanjut menurut Lashley (2000), mengatakan bahwa Hospitality membutuhkan situasi yang memberikan pelayanan kepada para tamu dimana pelayanan tersebut harus bisa memberikan kondisi memuaskan kepada tamu, dimana tamu tersebut harus dianggap sebagai satu-satunya tamu yang harus dilayani.

Pada dasarnya Hospitality memiliki makna kegiatan yang memberikan pelayanan yang ramah berdasarkan pada kebutuhan dasar terhadap tamu yang datang ke sebuah tempat tujuan wisata, restoran dan penginapan. Lebih lanjut, Hospitality juga memiliki makna yang mengarah pada hubungan antara tamu dan penyedia jasa atau tuan rumah (Mackenzie. 2009: P.20). Selain itu produk yang berhubungan dengan hospitality di antaranya adalah penyedia jasa makanan, minuman di sebuah restoran dan hotel. 
Hospitality pun mencakup semua yang dibutuhkan oleh tamu turis serta non turis dalam suatu destinasi wisata. Perasaan puas yang didapat oleh para tamu dalam kegiatan wisata akan dipengaruhi oleh banyak faktor seperti, daya tarik wisata tersebut, aksesibilitas, sarana dan jasa yang disediakan oleh pengelola, serta rasa aman yang didapat oleh wisatawan saat berwisata di tempat wisata tersebut.

Konsep hospitality beranggapan bahwa sebuah tempat wisata dapat dijadikan sebagai industri pariwisata. Ketika sebuah negara sudah menjadikan wisata sebagai industrinya, maka kewajiban dalam mengadopsi konsep hospitality menjadi sebuah keharusan, peran dan arti penting konsep ini mejadi krusial untuk diterapkan ke dalam sebuah "industri" agar "buyers" atau tamu dapat dengan puas menerima seluruh pelayanan yang diberikan kepada pelaku industri pariwisata tersebut.

Dalam hal ini, terdapat 4 pilar dalam manajemen hospitality dan pariwisata industri, yaitu Travel, Lodging, Food Service dan Recreation, seperti grafik yang akan disajikan di bawah 


\section{Grafik 1}

Diagram Hubungan Hospitality dan Industri Pariwisata (Chan Benny. 2003:P.20)

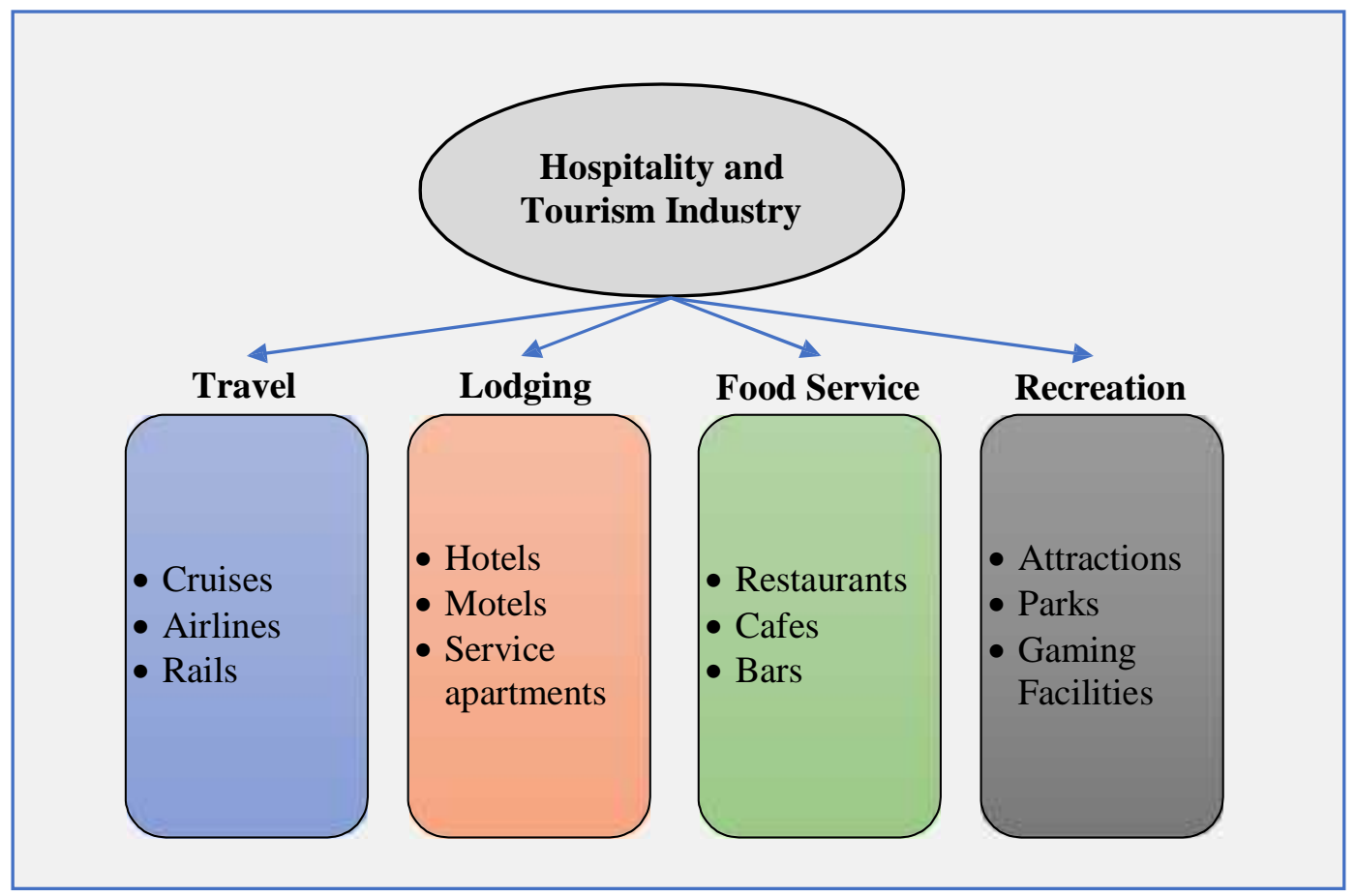

Berdasarkan grafik di atas, terlihat adanya kesatuan antara industri hospitality dan industri pariwisata, keempat pilar tersebut memiliki pengaruhnya masing-masing terhadap keberlangsungan suatu tempat wisata, karena jika salah satunya memiliki kekurangan, maka akan berpengaruh terhadap rasa puas yang didapat oleh para tamu dan dapat mempengaruhi pamor dari tempat wisata tersebut.

Travel, aksesibilitas, dan keamanan pilihan transportasi yang dimiliki untuk menuju dan pergi dari tempat wisata menjadi faktor utama ketertarikan para tamu untuk berkunjung ke tempat wisata. Kemudahan untuk mendapatkan tempat penginapan, 
terdapat beberapa pilihan di antaranya hotel, motel, homestay, dan sebagainya. Suatu tempat wisata pun tidak akan terlepas dari food service yang diberikan, suatu tempat wisata akan memiliki daya tarik apabila dibarengi dengan ketersediaan makanan yang memiliki cita rasa dan keunikan tersendiri. Kemudian sebagai tempat wisata, tentu tidak lepas dari bentuk rekreasi. Rekreasi ini dapat berupa atraksi, baik atraksi artifisial yang diciptakan oleh manusia seperti pagelaran seni dan tari, atau yang bersifat alamiah, seperti pemandangan pegunungan, bahari dsb. Lebih lanjut, atraksi juga erat hubungannya dengan taman bermain atau taman berwisata.

Pembahasan

Pelayanan secara maksimal yang diterapkan dalam konsep Hospitality, tentu akan menjadi satu kesatuan paket apabila didukung dengan potensi wisata yang ada di wilayah tempat hospitality tersebut diadopsi. Keberadaan tempat wisata tentu dilatarbelakangi dengan adanya atraksi/obyek wisata yang menurut kaca mata konsep hospitality dapat memicu lahirnya sebuah Industri pariwisata, selain itu atraksi yang dimiliki oleh suatu wilayah dianggap sebagai salah satu pilar dari industri pariwisata. Dalam hal ini Pulau Derawan sebagai wilayah yang masuk dalam wilayah segitiga terumbu karang dunia atau terkenal dengan sebutan "The Coral Treangle" menjadikan posisi Pulau Derawan sebagai wilayah yang sangat strategis untuk mengembangkan Industri wisata bahari yang ada di Pulau Derawan. Lebih lanjut, sebagai wilayah kecamatan, Pulau 
Derawan juga tidak sendirian di wilayah yang dikelilingi oleh pasir putih tersebut, masih ada beberapa gugusan pulau yang memiliki daya tarik wisatawan baik nasional dan internasional, di antaranya Pulau Maratua, Sangalaki dan Kakaban.

\section{Potensi Pulau Derawan}

Pulau Derawan seperti yang telah disebutkan sebelumnya masuk dalam wilayah segitiga terumbu karang dunia. Dimana wilayah ini berada di Selatan Samudera Pasifik, dan wilayah ini hanya dimiliki oleh enam negara di dunia, di antaranya Indonesia, Malaysia, Filipina, Papua Nugini, Timor Leste dan Kepulauan Solomon. Di wilayah ini, terdapat hampir 600 spesies terumbu karang dimana $76 \%$ dari total terumbu karang di dunia dapat ditemukan. Lebih lanjut, fakta yang tidak dapat dipungkiri bahwa hampir 574 spesies terumbu karang di segitiga terumbu karang ini $(95 \%)$ dan $72 \%$ dari total spesies terumbu karang yang ada di dunia berada di perairan Indonesia, dimana Raja Ampat menduduki peringkat pertama dan diikuti di kepulauan Derawan (Coral Triangle. 2017) 
Dinamika Global | Volume 03 | No. 02 | Desember 2018

\section{Gambar 3}

Kawasan Segitiga Terumbu Karang Dunia (Map of the coral. 2017)

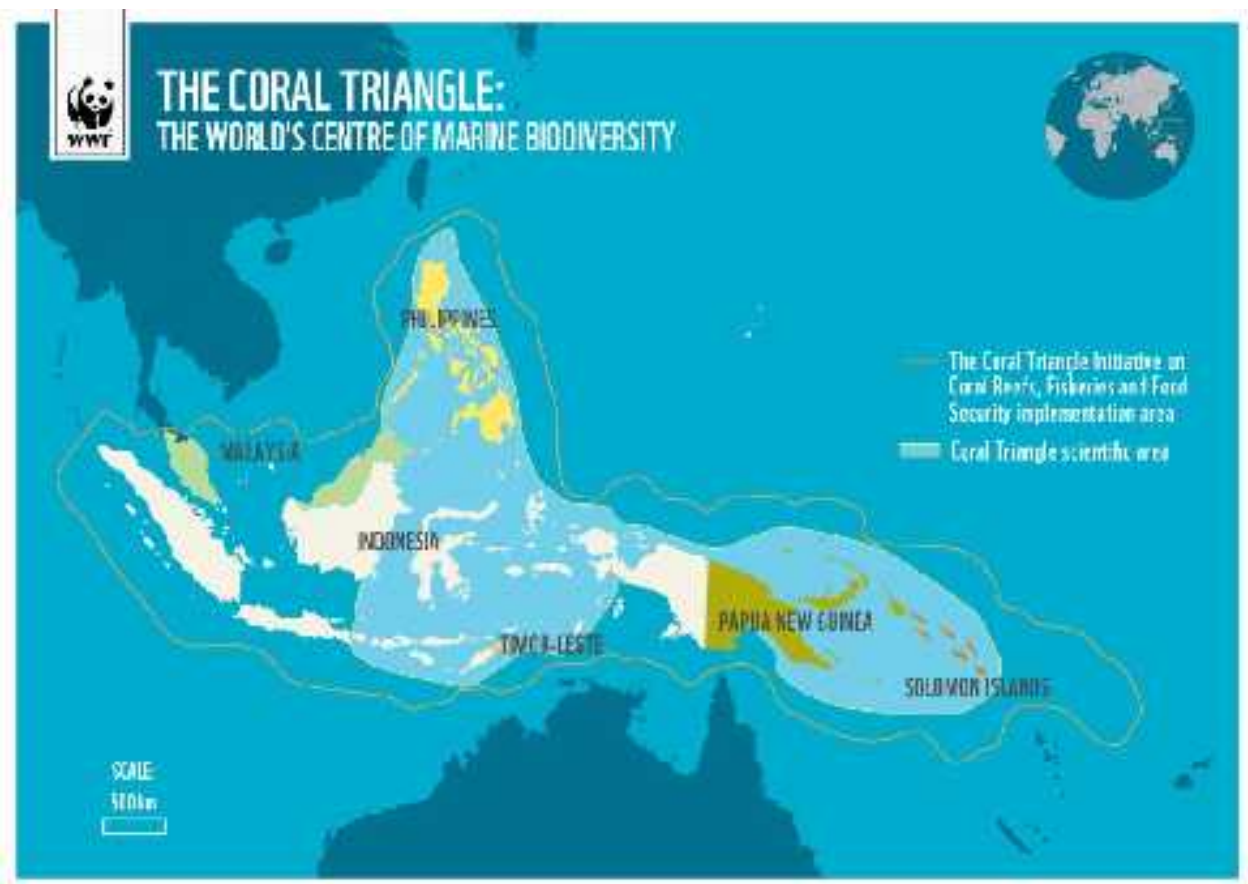

Gambar 4

Karang yang ada di Kepualaun Derawan (Dokumentasi Penulis. 2017)

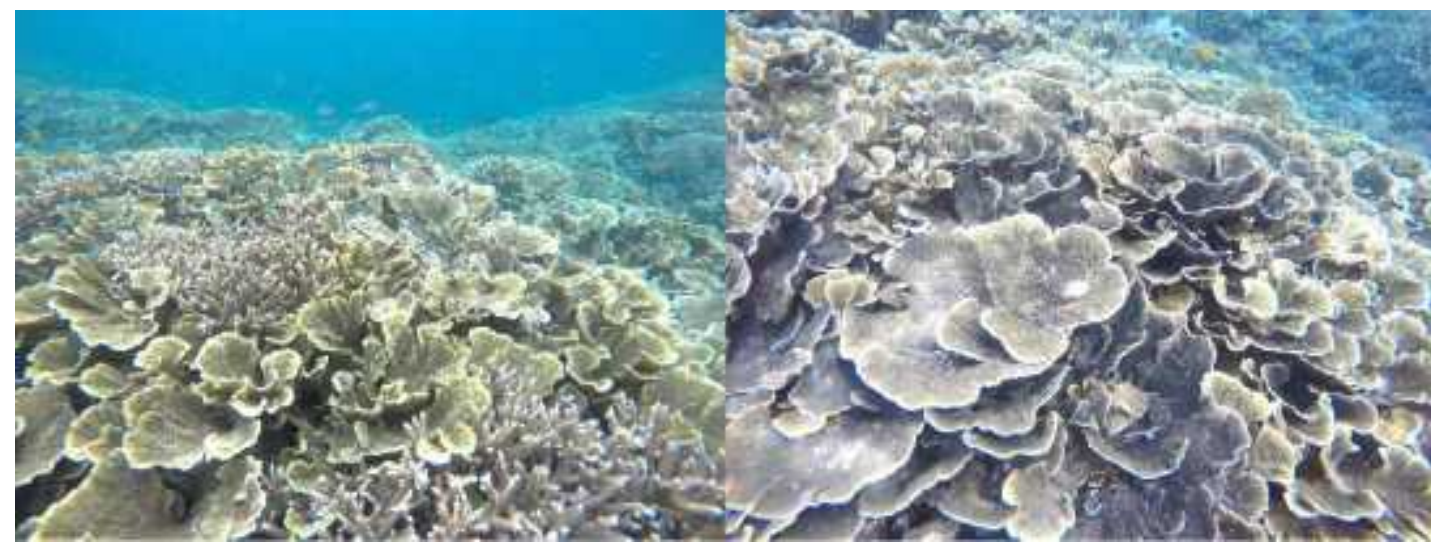


Kemudian dari segi jenis ikan, hampir 37\% total ikan terumbu karang (2.228 Spesies Ikan, dari total 6000 spesies) dapat ditemukan di wilayah ini, dan 56\% dari total ikan terumbu karang di wilayah Indo-Pasifik (4.050 spesies). Kemudian ditemukan juga bahwa hampir 8\% (235 spesies ikan terumbu karang) tergolong sebagai spesies endemik atau spesies lokal dan terbatas hanya ditemukan di wilayah ini. Dari total keseluruhan wilayah ini, terdapat 4 wilayah yang memiliki tingkat diversitas tertinggi keberadaan spesies endemik, di antaranya Selat Sunda Indonesia, Papua Nugini, Kepulauan Solomon dan Filipina bagian tengah) (WWF Panda. 2017).

Kemudian, selain banyaknya spesies ikan terumbu karang tersebut, wilayah ini juga menjadi tempat habitat dari beberapa mamalia ikan, di antaranya Paus Biru (The Blue Whale) (binatang terbesar yang hidup di dunia), kemudian Paus Sperm (Sperm Whales), lalu Lumba-lumba punggung bungkuk Indo-Pasifik serta Dugongs, dimana mamalia ini sudah termasuk hewan yang terancam punah. Lebih lanjut, dari total 7 spesies penyu di dunia, 6 di antaranya berada di wilayah segitiga terumbu karang dunia ini, dan 2 di antaranya dapat dengan mudah ditemukan di Pulau Derawan.

Dengan wilayah yang kaya akan atraksi wisata bahari yang dimiliki oleh Pulau Derawan, tentunya harus didukung oleh pilar atau sektor akomodasi guna memudahkan para tamu yang ingin berkunjung baik untuk melakukan rekreasi atau penelitian. Dalam konsep hospitality, terdapat dua fasilitas atau akomodasi yang termasuk dalam sektor pendukung penerapan konsep yang 
mengutamakan keramahtamahan dalam pelayanan. Dalam hal ini adalah Lodging dan Food Service. Lodging sendiri terdiri dari tempat penginapan dan beberapa tempat pendukung dalam mendukung keberadaan atraksi bawah laut yang dimiliki Pulau Derawan. Sebagai pulau yang terkenal sebagai destinasi wisata dan dilengkapi dengan akomodasi yang sangat lengkap, serta pernah dipercaya menjadi salah satu tempat dari penyelenggaraan dua cabang olah raga dalam Pekan olah raga nasional (PON) tahun 2008. Terbukti, Pulau Derawan pada kenyataannya dipenuhi dengan rumah - rumah masyarakat yang disewakan kepada para wisatawan berupa home stay. Selain itu, cottage-cottage yang menjorok ke laut juga terdapat di pinggirpinggir pantai dengan menawarkan harga yang bervariasi. Berikut akan disajikan data tempat penginapan yang ada di Pulau Derawan: 
Tabel 1

Daftar Resort, Cottage dan Homestay di Pulau Derawan

(Dinas Kebudayaan. 2017)

\begin{tabular}{|c|l|l|}
\hline \multicolumn{3}{|c|}{ Kecamatan Pulau Derawan } \\
\hline \multicolumn{3}{|c|}{ Resort } \\
\hline 2 & PT. BMI & Derawan \\
\hline 3 & Sangalaki Manta Paradise & Derawan \\
\hline 4 & Derawan Dive Lodge & Derawan \\
\hline 5 & LapautaDerawan Resort & Derawan \\
\hline \multicolumn{3}{|c|}{ Penginapan/Cottage } \\
\hline 1 & Danakan & Derawan \\
\hline 2 & Derawan Lestari 1 & Derawan \\
\hline 3 & Derawan Lestari 2 & Derawan \\
\hline 4 & Derawan Lestari 3 & Derawan \\
\hline 5 & Ilham & Derawan \\
\hline 26 & LosmenTerapung & Derawan \\
\hline \multicolumn{3}{|c|}{ Homestay } \\
\hline 1 & Qori & Derawan \\
\hline 2 & Syahnar & Derawan \\
\hline 3 & Yuliana & Derawan \\
\hline 4 & Wanmas & Derawan \\
\hline 5 & Tiga Putra & Derawan \\
\hline $6-96$ & & Derawan \\
\hline 97 & Heriyanto & Derawan \\
\hline 98 & Junaidi & \\
\hline
\end{tabular}

Berdasarkan tabel di atas, terlihat terdapat 98 Homestay, 26 Penginapan/cottage dan 5 resort. Dengan banyaknya akomodasi berupa penginapan yang dimiliki Pulau Derawan, tidaklah heran, pulau ini dianggap sebagai salah satu pulau 
kunjungan dan menjadi tempat tinggal dari hampir seluruh wisatawan yang datang untuk melakukan wisata bahari di Kepulauan Derawan. Harga yang ditawarkan untuk menginap di penginapan yang di Pulau Derawan pun bervariasi. Mulai dari Rp 200.000 untuk satu kamar homestay, sampai dengan Rp 1.500.000 untuk satu kamar di resort yang menghadap lautan. Selain itu, seperti yang telah disebutkan di atas, Pulau Derawan juga memiliki sarana pendukung seperti rumah makan/cafe. Berikut akan disajikan:

Tabel 2

Data Rumah Makan di Pulau Derawan (Dinas Kebudayaan.

2017)

\begin{tabular}{|l|l|l|}
\hline \multicolumn{2}{|c|}{ Kecamatan Derawan } \\
\hline 1 & RM. Ilham & Pulau Derawan \\
\hline 2 & RM. April Resto & Pulau Derawan \\
\hline 3 & RM. Karlina & Pulau Derawan \\
\hline 4 & RM. Agusty & Pulau Derawan \\
\hline 5 & RM. Nur & Pulau Derawan \\
\hline
\end{tabular}

Terkait dengan ketersediaan rumah makan yang ada di Pulau Derawan berdasarkan hasil pengamatan penulis, ternayata terdapat lebih banyak rumah makan dibandingkan dengan data yang dimiliki oleh Dinas Kebudayaan dan Pariwisata Kabupaten Tanjung Redeb seperti data yang tertera di atas. Kemudian dalam sajian makan yang ditawarkan Pulau Derawan, tentu hampir sebagian besar bercita rasa makanan laut. Dimana semua bahan baku yang disajikan di setiap rumah makan hampir mayoritas merupakan produksi Pulau Derawan sendiri yang dilakukan oleh para nelayan. Sehinggga terkait dengan kesegaran makanan 
sangat tidak diragukan. Harga yang ditawarkan untuk satu porsi makanan pun juga sangat beragam dan tergantung dari selera konsumen, mulai dari Rp 30.000 sampai dengan Rp 150.000 per porsi.

Kemudian pilar ketiga dari konsep hospitality yakni terkait travel perjalanan. Dimana pilar ini tentulah sangat memiliki peran yang vital untuk suksesnya Pulau Derawan sebagai destinasi wisata bahari. Adapun moda transportasi yang dapat digunakan untuk sampai ke pulau yang terletak di kawasan segitiga terumbu karang, menggunakan moda transportasi air. Namun sebelumnya untuk sampai ke pulau tersebut, para turis harus singgah di Kabupaten Berau atau yang biasa disebut dengan Tanjung Redeb. Kabupaten Berau/Tanjung Redeb dapat ditempuh dengan menggunakan trasnportasi udara dan darat. Namun akses termudah dari luar Pulau Kalimantan, tentu dengan menggunakan pesawat terbang. Jumlah penerbangan dari dan menuju Kabupaten Berau/Tanjung Redeb, jika memulai perjalanan dari kota Balikpapan (Pintu Gerbang Provinsi Kalimantan Timur) maka terdapat sekitar 6 sampai 7 penerbangan per harinya, dengan maskapai di antaranya Garuda Indonesia, Sriwijaya Airlines dan Lion Air, terdapat satu maskapai lagi yang menyediakan perjalanan menuju Kabupaten Berau yakni Kalstar, namun karena terdapat beberapa masalah yang menimpa tubuh manajemen perusahaan ini, maka izin penerbangan maskapai ini sementara dibekukan oleh Kementerian Perhubungan RI (Kemenhub. 2017). Rata-rata harga 
tiket pesawat yang ditawarkan bervariasi sekitar Rp 400.000 sampai dengan Rp 700.000.

Sesampainya di Tanjung Redeb, para turis dihadapkan dengan beberapa pilihan untuk sampai ke Pulau Derawan. Pertama menempuh melalui jalan darat diharuskan melakukan perjalanan darat sekitar dua jam tiga puluh menit sampai tiga jam menuju Kecamatan Tanjung Batu, dengan biaya per satu orangnya Rp 100.000 - Rp 150.000, serta Rp 500.000 untuk charter satu mobil. Sarana transportasi darat ini dapat dengan mudah ditemui di Tanjung Redeb dan tersedia melalui para agen dan biro perjalanan. Sesampainya di Tanjung Batu, maka para turis diwajibkan membayar kontribusi di Pelabuhan Tanjung Batu sekitar Rp 15.000 dan melanjutkan perjalanan menuju Pulau Derawan selama hampir tiga puluh menit dengan menggunakan speedboat. Biaya untuk menyebrang sampai ke Pulau Derawan adalah Rp 100.000 per penumpang. Speed boat sudah dilengkapi dengan pelampung untuk masing - masing penumpang, dan beberapa informasi terkait destinasi wisata yang ada di Kepulauan Derawan, bahkan berdasarkan hasil observasi yang penulis lakukan, pengemudi kapal cepat tersebut memiliki fasilitas kamera "Go Pro" dan dapat dipinjamkan secara cuma-cuma kepada para penumpang. 


\section{Gambar 5}

Kondisi Speed Boat Kapasitas 5 Penumpang (Dokumentasi

Penulis. 2017)

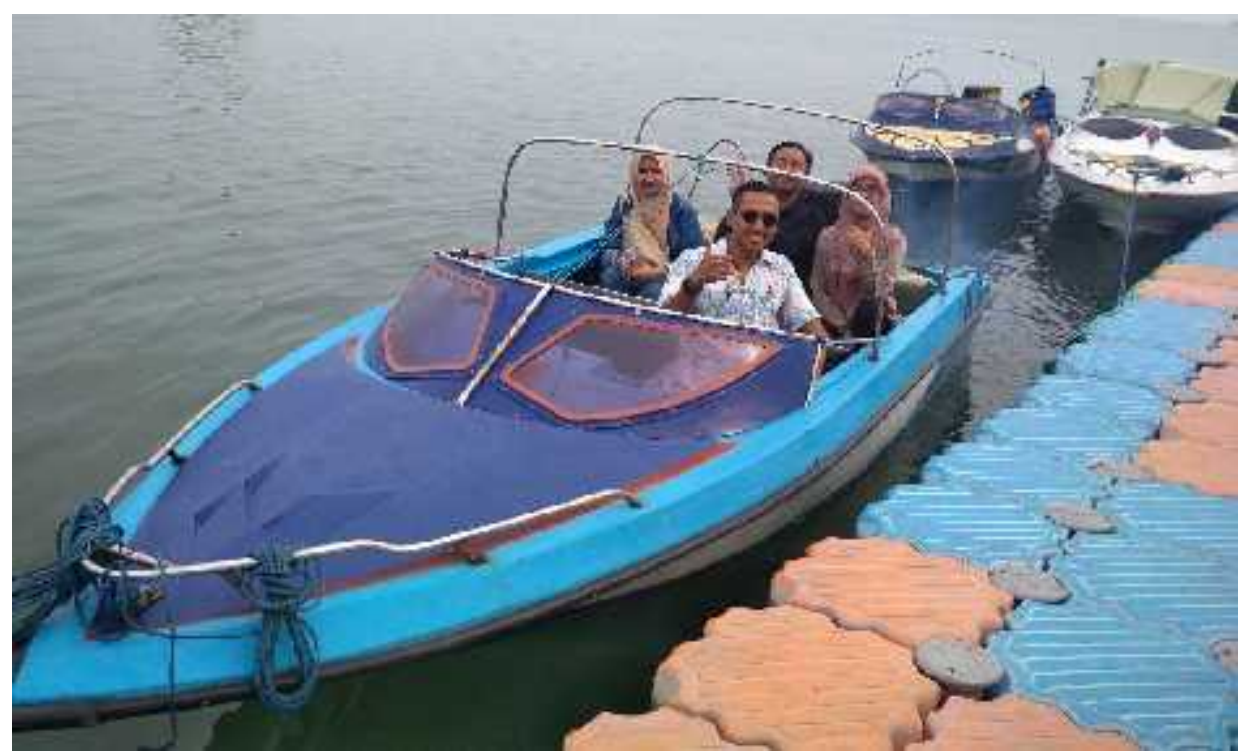

Berdasarkan hasil wawancara yang dilakukan oleh penulis dengan salah satu penyedia jasa wisata di Pulau Derawan yakni Scuba Junkie, untuk memberikan pelayanan maksimal, bahkan penyedia jasa tersebut dapat menyediakan jasa penjemputan bagi para turis yang berkunjung sejak di Bandara Kalimarau Kabupaten Berau, sampai tiba di Pulau Derawan, sehingga dipastikan para turis tersebut tidak akan mengalami masalah yang berarti selama perjalanan menuju Pulau Derawan.

Selain kapal cepat berkapasitas lima penumpang, penyedia jasa juga memiliki banyak ukuran kapal berukuran sedang dan besar. Terdapat kapal dengan ukuran 15-20 penumpang, dan kapal tersebut dilengkapi dengan tempat tabung oksigen untuk kegiatan scuba diving. Lebih lanjut, terkait dengan dermaga yang berada di Pulau Derawan, terdapat beberapa dermaga yang dapat 
menerima para pengunjung dan satu dermaga utama dimana dermaga tersebut mengapung terletak di sebelah kanan dan kiri dermaga utama. Berdasarkan pengamatan penulis, dermaga tersebut tergolong dermaga yang sangat aman untuk dilalui.

\section{Gambar 6}

Dermaga Apung/Utama Pulau Derawan (Dokumentasi

Penulis.2017)

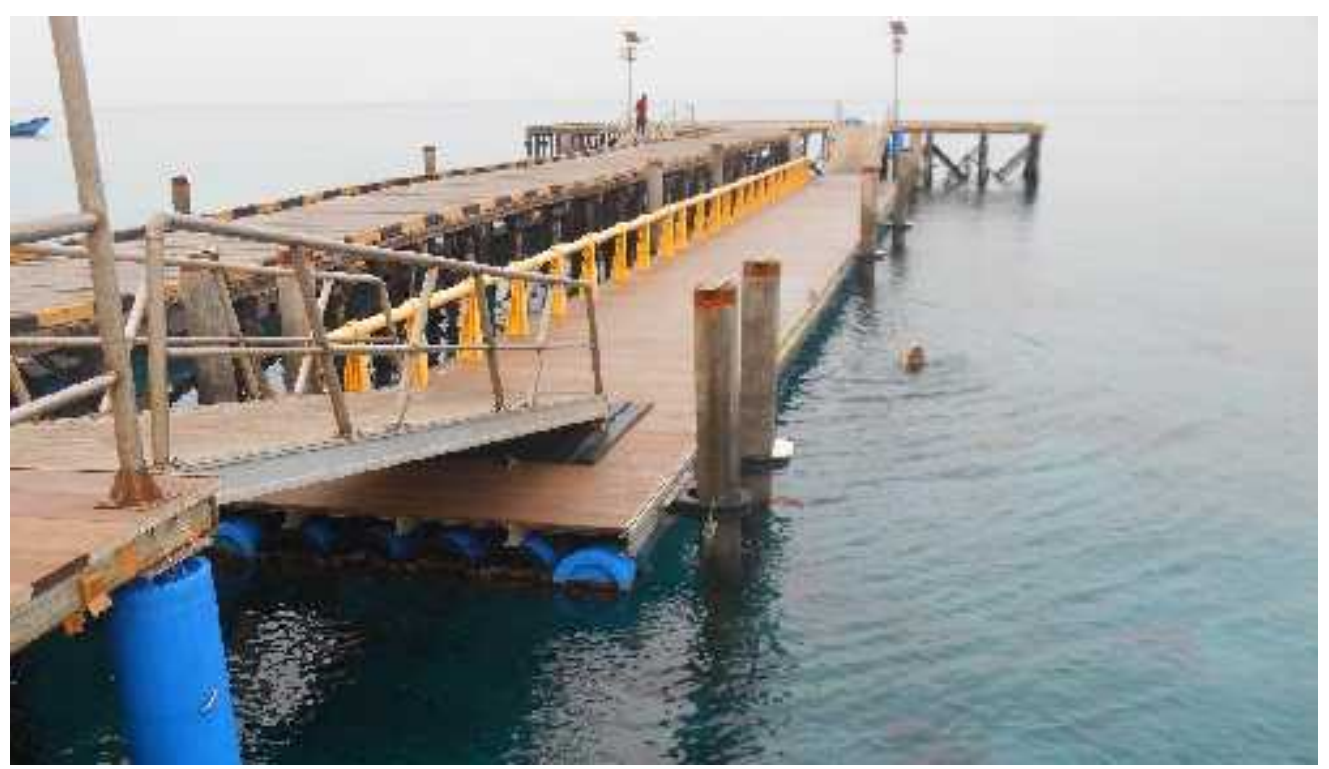

Dalam industri pariwisata, kehadiran akan dukungan Sumber Daya Manusia (SDM) yang handal dalam bidang kepariwisataan juga menjadi hal yang mutlak. Pulau Derawan sebagai wilayah yang terkenal dengan wisata bahari, juga memiliki SDM yang terlatih dalam kegiatan bahari. Pelatih pelatih/instruktur menyelelam/diving dapat ditemukan dengan mudah di beberapa resort dan tempat penyewaan alat selam. Insturktur ini dapat melakukan berbagai pelatihan kepada para 
pengunjung yang ingin melakukan penyelaman di beberapa titik menyelam yang dimiliki Pulau Derawan.

Secara umum jika melihat penjelasan sebelumnya di atas, terlihat bahwa Pulau Derawan telah mengaplikasikan pilar-pilar dari industri pariwisata tersebut, dan mengadopsi konsep keramahtamahan yang dapat membuat tamu/pengunjung dapat menikmati segala fasilitas yang ada dan dipastikan akan berdampak positif bagi eksistensi Pulau Derawan. Namun pada praktiknya di lapangan, pulau yang menjadi salah satu tempat bertelurnya beberapa jenis penyu ini, juga dihadapkan dengan beberapa masalah yang cukup mengkhawatirkan bagi keberadaan Pulau Derawan ini sendiri.

Masalah yang dihadapi Pulau Derawan

Berdasarkan hasil pengamatan dan wawancara yang dilakukan kepada para pejabat di Kabupaten Berau sampai di tingkat kampung, di antaranya Kepala Dinas Kebudayaan dan Pariwisata, Camat Tanjung Batu, Kepala Kampung Kecamatan Pulau Derawan, sepakat masalah abrasi adalah ancaman bagi eksistensi keindahan Pulau Derawan. Menurut kamus besar Bahasa Indonesia, pengertian abrasi adalah fenomena proses pengikisan pantai oleh gelombang laut. Jika dirunut dari awal mula mulainya masalah ini, sebenarnya ketika Pulau Derawan menjadi salah satu venue/tempat penyelenggaraan dua cabang olah raga pada penyelenggaraan Pekan Olah Raga Nasional Tahun 2008, dimana pada saat itu pembangunan pemukiman dilakukan 
secara massive, banyak warga baru berdatangan dan mendirikan bangunan disepanjang bibir pantai. Dengan adanya pemukiman yang padat tersebut berdampak positif dan negatif.

Dampak positif tentu Pulau Derawan semakin dikenal oleh masyarakat Indonesia dan masyarakat internasional, dimana rumah-rumah penduduk tersebut juga menjadi Homestay bagi para pengunjung. Namun banyak masyarakat dan bahkan sebagian pemerintah setempat tidak mengetahui dampak dari adanya perumahan yang berada di pinggiran pantai tersebut, dimana dengan banyak pemukiman warga tersebut telah menyebabkan abrasi yang terjadi di ujung timur Pulau Derawan.

Selain menghadapi masalah abrasi, pulau Derawan juga dihadapkan dengan kondisi sampah yang semakin hari semakin banyak. Hal ini konsekuensi dari semakin banyaknya turis yang berkunjung ke pulau derawan. Pernah ada satu solusi namun hanya berupa wacana yang ditawarkan Pj.S Kepala Kampung kepada para turis agar pulau derawan tetap terbebas dari persoalan sampah yakni meminta para turis untuk membawa kembali sampah plastik yang mereka bawa dari luar Pulau Derawan dan membuang ke tempat sampah yang telah ditentukan di Tanjung Batu. Namun banyak masyarakat dan perangkat kampung merasa tidak elok apabila kebijakan tersebut diterapkan kepada para turis yang berkunjung ke Pulau Derawan. Sehingga salah satu solusi yang dilakukan pejabat Pulau Derawan dengan membakar sampah dengan alat pembakar sampah medis atau yang disebut incenerator yang dibangun oleh Dinas Kesehatan. 
Pada awalnya incenerator ini berfungsi untuk membakar sampah medis milik puskesmas Pulau Derawan, sehingga peruntukannya tidak untuk masyarakat umum. Namun pada akhirnya berkat usaha Pj.S Kepala Kampung, alat yang semula hanya digunakan untuk membakar sampah medis, beralih dapat membakar sampah yang diproduksi oleh masyarakat umum, sehingga sampah medis milik puskesmas dibawa ke Tanjung batu untuk diproses. Selain itu, salah satu solusi terkait pengelolaan sampah ini adalah dengan melibatkan secara aktif Kelompok Sadar Wisata (Pokdarwis), sehingga jika terdapat bantuan dari pihak ketiga harapannya kelompok ini dapat memanfaatkan secara maksimal pengelolaan bantuan tersebut untuk kemajuan pulau derawan.

Kemudian terkait dengan upaya pemerintah melakukan promosi terkait pulau Derawan juga dirasa masih kurang, sekalipun jika melihat uang rupiah dengan pecahan 20.000 terdapat gambar Pulau Derawan, namun pada kenyataanya hal itu merupakan inisiatif dari gubernur Bank Indonesia ketika berkunjung ke Pulau Derawan. Pemerintah daerah dirasa masih kurang dalam menarik turis-turis mancanegara untuk datang dan berkunjung secara khusus di Pulau Derawan. Keberadaan pusat informasi turis saja, belum dapat ditemukan di Pulau Derawan sehingga hal ini masih menyulitkan para turis yang datang untuk melihat informasi terkait tempat-tempat menarik di Pulau Derawan.

Dilain pihak jika melihat berdasarkan potensi pulau derawan seperti yang telah disebutkan sebelumnya bahwa letak 
geografis Pulau Derawan di segitiga terumbu karang merupakan sebuah kekhasan tersendiri yang tidak dimiliki banyak pulau di dunia. Hal ini diperburuk dengan kebijakan pemerintah daerah yang lebih cenderung melaksanakan berbagai kegiatan untuk menarik wisatawan selain di Pulau Derawan yakni di Pulau Maratua. Lebih lanjut jika dilihat dari segi infrastrukur, Pulau Maratua sudah memiliki bandara, dan di pulau tersebut juga terdapat resort - resort yang memikiki pantai pasir putih yang berdasarkan hasil observasi memiliki kualitas dan panorama lebih baik dari pada Pulau Derawan. Hal ini yang dikhawatirkan masyarakat Pulau Derawan. Dengan adanya penerbangan langsung Balikpapan - Maratua dan bahkan dari Tarakan Maratua, akan menyebabkan pulau Derawan menjadi destinasi yang dikesampingkan. Sedangkan jika dilihat dari jumlah penduduk, dari beberapa pulau yang berada di gugusan kepulauan derawan, pulau derawanlah yang memiliki jumlah penduduk terbanyak dan dilengkapi dengan infrastruktur yang memadai.

Berdasarkan fenomena ini terlihat kebijakan pemerintah yang kurang mendukung eksistensi Pulau Derawan, sehingga kebijakan tersebut tidak terpusat untuk pengembangan pulau Derawan namun menyebar ke berbagai destinasi wisata yang ada di kepulauan derawan. Pulau Derawan sendiri berdasarkan hasil wawancara Pj.S Kepala Kampung lebih cocok disebut sebagai destinasi kunjungan, bukan desa wisata, karena untuk meraih predikat desa wisata tentu harus didukung dengan atraksi atraksi yang dapat memukau para turis. Penulis berargumen 
sesungguhnya Pulau Derawan sudah pantas untuk disebut sebagai desa wisata, karena disekitar Pulau Derawan juga terdapat banyak titik-titik wisata menyelam/diving dan wisata penyu. Hal ini seharusnya yang menjadi prioritas pemerintah untuk menjadikan Pulau derawan sebagai destinasi wisata yang bekelanjutan. Penulis pun juga melakukan observasi bahwa jernihnya air yang berada di sekitar Pulau Derawan sesungguhnya menjadikan daya tarik tersendiri bagi Pulau Derawan, dimana seolah-olah para turis diposisikan sedang berada di dalam aquarium dengan keindahan flora dan fauna yang berada di bawah air. 


\section{Gambar 7}

Titik Menyelam/Diving Spot (Kotak Merah)

di Pulau Derawan (Derawan Dive Lodge. 2017)

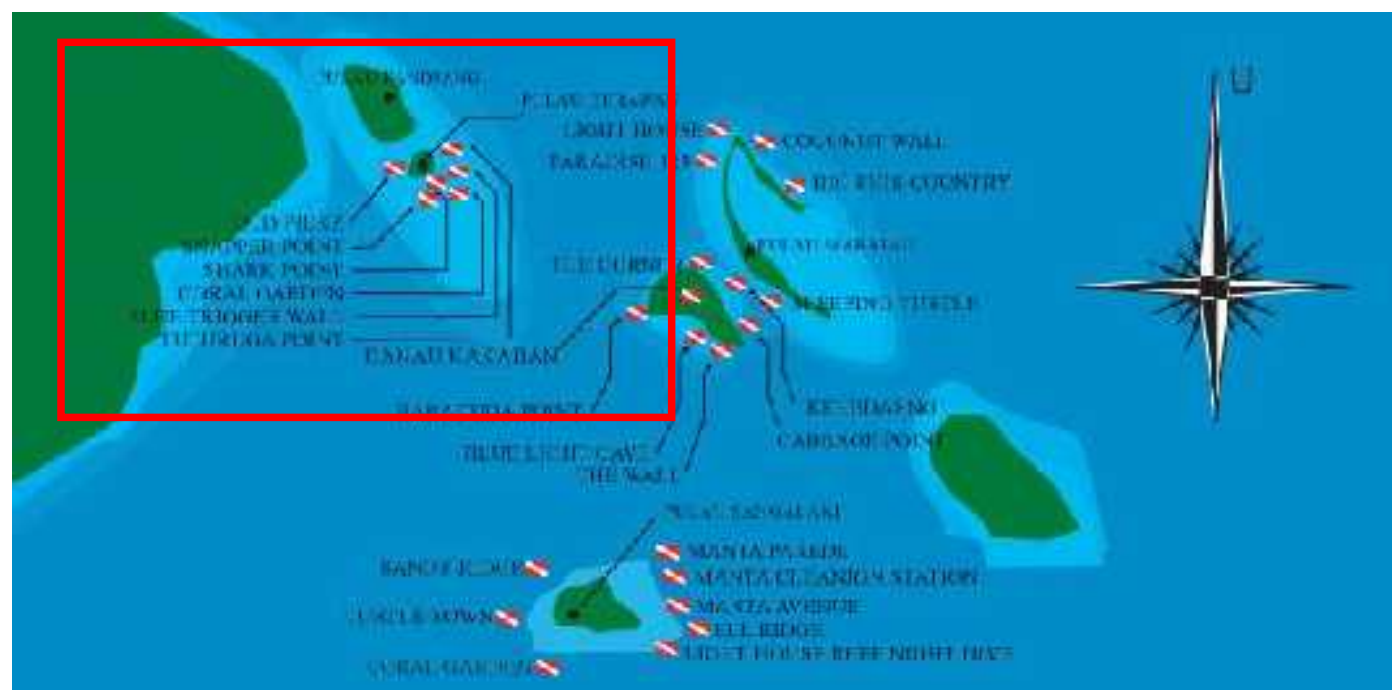

Terkait promosi yang penulis singgung sebelumnya, bahwa memang pemerintah daerah masih kurang dalam melaksanakan kegiatan - kegiatan yang menarik wisatawan, misalnya mengadakan festival budaya dan lain - lain. Sehingga kedepan promosi - promosi harus dilakukan dengan berbagai cara.

Upaya Pengembangan Potensi Pulau Derawan oleh Pemerintah Kabupaten Berau

Berangkat dari permasalahan yang dihadapi Pulau Derawan, tentu pemerintah khususnya yang berada di Pulau Derawan tidak tinggal diam dengan kondisi tersebut. Harus ada inovasi - inovasi agar menjadikan Derawan sebagai tujuan destinasi wisata yang tetap menarik minat para wisatawan. Seperti yang telah disinggung sebelumnya banyaknya 
infrasturktur berupa akomodasi yang ada di Pulau Derawan menjadikannya sebagai pulau yang sangat potensial menjadi pusat dari wisata yang ada di Kepulauan Derawan. Hal ini salah satunya diwujudkan dengan kerjasama dengan penyedia jasa menyelam, salah satunya adalah Scuba Junkie. Berdasarkan wawancara Pj.S Kepala Kampung, memberikan izin kerja tenaga asing di Pulau Derawan yakni Scuba Junkie adalah salah satu strategi untuk mendatangkan turis - turis asing agar datang dan berwisata di Pulau Derawan. Mengingat Scuba Junkie adalah salah satu organisasi penyedia jasa wisata bahari yang sudah terkenal dan memiliki kantor representatif di banyak negara, sehingga promosi yang dilakukan tentu akan sangat dengan mudah dan hemat biaya. Hal ini menjadi lebih efisien dibanding harus melakukan promosi dengan dana APBD pemerintah Kabupaten Berau yang tentunya harus melewati berbagai macam birokrasi yang memakan waktu tidak singkat.

Lebih lanjut, pemerintah Kecamatan Pulau Derawan juga berencana akan membangun dermaga satu pintu dimana akan menjadikan pusat dermaga yang ada di Pulau Derawan, dimana di dermaga tersebut rencananya akan dibuat tempat pusat informasi pariwisata yang ada di pulau derawan dan pusat pencatatan statistik pengunjung, sehingga akan dengan mudah pencatatan data bagi pengunjung yang masuk ke Pulau Derawan. Rencana ini akan dilaksanakn dengan anggaran tahun 2018.

Kemudian terkait dengan abrasi pantai, pemerintah sudah bekerjasama dengan peneliti asal Universitas Gadjah Mada (UGM) untuk membangun pencegah abrasi, namun dana untuk 
mewujudkan alat tersebut masih terkedala dalam hal pembiayaan. Lebih lanjut solusi jangka panjang yang diharapkan pemerintah Kecamatan Pulau Derawan adalah peningkatan status bandara Kalimarau Berau menuju bandara internasional. Hal ini dianggap penting karena seperti yang terjadi di saat sekarang, dimana banyak turis yang berkunjung di Pulau Derawan dan Kepulauan Derawan adalah turis yang berasal dari Hongkong dan Tiongkok, sehingga apabila Kalimarau tidak meningkat statusnya menjadi bandara internasional, dikhawatirkan para turis tersebut akan terbang menuju Pulau Maratua bukan menuju Bandara Kalimarau Berau dari Tarakan, karena seperti yang diketahui bahwa Bandara Juwata Tarakan sudah berstatus bandara internasional, dan letaknya yang sangat stategis di perbatasan antara Indonesia dan Malaysia. Hal ini akan menjadi buruk bagi pendapatan kabupaten berau dan pulau derawan secara khusus, karena turis - turis asing melakukan perjalanan langsung dari Tarakan menuju Pulau Maratua.

Terkait dengan peningkatan SDM masyarakat Pulau Derawan, pemerintah juga telah melaksanakan pelatihan bahasa inggris bagi masyarakat lokal dengan penggunaan dana bersumber dari dana kampung. Kegiatan ini telah diikuti oleh masyarakat, teruma masyarakat yang terlibat secara langsung dalam kegiatan pariwisata yang ada di Pulau Derawan di antaranya pemilik penginapan, rumah makan dan pemandu wisata (Duta Wisata Kab. Berau. 2017). 
Kesimpulan

Berdasarkan analisa pada bab-bab yang telah dibahas sebelumnya maka Pulau Derawan memiliki potensi yang sangat besar untuk menjadi destinasi wisata utama di Indonesia. Seperti yang telah dibahas sebelumnya, Segitiga Terumbu Karang merupakan wilayah yang dilindungi bukan hanya oleh pemerintah Indonesia namun juga dunia karena merupakan pusat keanekaragaman hayati laut yang penting bagi laut dunia. Hal ini tentu saja dapat menjadi daya tarik yang sangat besar bagi pengunjung sebagai wisatawan maupun peneliti.

Kemudian, dari sisi manajemen hospiltality yang terbagi dalam 4 kriteria yaitu, Travel, Lodging, Food Service, dan Recreation maka Pulau Derawan sudah cukup memenuhi kebutuhan pengunjung. Para penyedia jasa wisata seperti pengelola penginapan, rumah makan maupun sarana transportasi dan rekreasi secara umum telah menjalankan manajemen hospitality dengan cukup baik. Perkembangan wisata di pulau ini juga terlihat cukup pesat, dilihat dari bertambahnya fasilitas-fasilitas jasa wisata sejak tahun 2008 ketika Pulau Derawan dijadikan tuan rumah turnamen voli pantai pada PON 2008.

Di sisi lain, Pulau Derawan juga memiliki beberapa permasalahan seperti masalah abrasi yang terus menggerus garis pantai, sistem pengelolaan sampah yang belum memadai, serta kurang gencarnya promosi wisata oleh pemerintah daerah untuk Pulau Derawan. Hal-hal tersebut, jika tidak segera ditangani dengan cepat dan tepat dikhawatirkan dapat menurunkan nilai 
jual Pulau Perawan bagi para wisatawan. Hal yang lebih disayangkan lagi adalah peran Pemerintah Daerah dalam menangani permasalahan-permasalahan tersebut dirasa belum maksimal oleh masyarakat derawan.

Saran

Beberapa permasalahan di Pulau Derawan pada dasarnya dapat dibenahi. Namun, hal ini tentu saja kembali pada rasa tanggung jawab serta kerjasama semua pihak yaitu Pemerintah Daerah, pengelola wisata, serta penduduk Pulau Derawan sendiri.

Terkait masalah abrasi yang selama ini menjadi keresahan penduduk, sebenarnya dapat diselesaikan jika saja penduduk atau pengelola jasa penginapan bersedia melakukan perombakan bangunan yang menjorok ke laut. Hal ini juga harus disertai dengan peningkatan pengawasan Pemerintah Daerah terhadap pembangunan yang dilakukan di Pulau Derawan.

Masalah lain seperti pengelolaan sampah serta kurangnya promosi wisata Pulau Derawan, harusnya mendapat perhatian lebih dari pihak pemerintah daerah karena hal ini bukan semata untuk meningkatkan nilai wisata Pulau Derawan baik bagi wisatawan namun juga secara umum dapat meningkatkan pendapatan daerah maupun nasional. Di sisi lain, peran penduduk lokal serta wisatawan juga dirasa sangat penting dalam menjaga kebersihan, ketertiban serta peningkatan popularitas wisata pulau ini. 
Referensi

Buku/Jurnal/Internet

Chan Benny Dr. 2003. Tourism and Hospitality Studies Introduction to Hospitality

Fine-tuned version. Curriculum Development Institute Education Bureau Hongkong.

Coral Triangle, $\quad \underline{\text { htp://www.menlh.go.id/indonesia-dan- }}$ pertemuan-segitigaterumbu-karang/

Coral triangle facts, tersedia di

http:/ / wwf.panda.org/what_we_do/where_we_work/coralt riangle/coraltrianglefacts /

Derawan Island, http://disbudpar.beraukab.go.id/kepualuanderawan/,

Donate for dugongs, tersedia di

http://www.australiangeographic.com.au/society/fundrais ing/2014/02/donate-for-dugongs

Foreign

tourists

https://www.bps.go.id/linkTabelStatis/view/id/1393,

arrival,

Indonesia's

foreign

exchange,

http://www.kemenpar.go.id/userfiles/devisa2011-

2015.pdf, diakses pada tanggal 10 Agustus 2017

Instrumen pembayaran tunai, tersedia di

http://www.bi.go.id/id/sistem-

pembayaran/instrumen/gambar-

uang/Contents/Default.aspx

Irawati Singarimbun, Metode Penelitian Sosial, LP3ES, Jakarta, 1989, hal. 70-71

Jumlah Penduduk Pulau Derawan, diakses pada tanggal 
https://beraukab.bps.go.id/webbeta/website/pdf_publika si/Kecamatan-Pulau-Derawan-Dalam-Angka-2017.pdf

Maleong, Lexy.J. 2002. Metodologi Penelitian Kualitatif. Bandung: PT.

Remaja Rosdakarya, hal. 58

Map of the coral tiangle, tersedia di

http://wwf.panda.org/_core/general.cfc?method=getOrigin alImage\&uImgID $=\% 26 \% 2 \mathrm{AB} \% 24 \% 2 \mathrm{~B} \% 20 \% 5 \mathrm{EK} 6 \% 0 \mathrm{~A}$

Miles \& Huberman, 1992. Analisis Data Kualitatif. Jakarta

Nasution, S. 1988. Metode Penelitian Naturalistik Kualitatif. Bandung. Penerbit Tarsito. P. 5.

Popova Daniela, Assoc. Prof. 2012. Hospitality Management. Lecturer Series.

Wiryawan Budi. 2005. Ringkasan Eksekutif. Menuju Kawasan Konservasi Laut Berau Kalimantan Timur Status Sumberdaya Pesisir dan Proses Pengembangan KKL. . 2004. Profil Kepulauan Derawan, Kabupaten Berau Kalimantan Timur.

Wolfer Looren, 2006. Real Research: Conducting and Evaluating Research in the Social Sciences. 1st edition. Routledge

Dokumen Elektronik/Fisik :

1. Data Agen dan Biro Kabupaten Berau

2. Data Akomodasi Kabupaten Berau

3. Data Bilyard Kabupaten Berau

4. Data Karaoke Kabupaten Berau

5. Data Kunjungan Perbulan dan Tahun Kabupaten Berau

6. Data Penyewaan Alat Selam Kabupaten Berau

7. Data Rumah Makan Kabupaten Berau

8. Data Salon Kabupaten Berau

9. Brosur Pulau Derawan

10. CD Profil Pulau Derawan 
Wawancara :

1. Kepala Kampung Kecamatan Pulau Derawan

2. Sekretaris Dinas Pariwisata Kabupaten Berau/Tanjung Redeb

3. Camat Tanjung Batu

4. Pengusaha Rumah Makan Pulau Derawan

5. Pengusaha Diving Scuba Junkie

6. Tokoh Masyarakat Pulau Derawan

7. Pengunjung Pulau Derawan 